\title{
Staying On The Cutting Edge Of Student Active Learning Through Real World Engagement
}

Dan A. Yates, University of Findlay, USA

Chris Ward, University of Findlay, USA

\begin{abstract}
This paper introduces a new approach to teaching and learning that uses a partnership model that pairs small business owners (provided by the Small Business Development Center-SBDC) with teams of college students within a college course. The goal of this partnership model is to provide guidance and recommendations for the business owner through a comprehensive business plan that is completed by an assigned student team. This is an excellent opportunity for the students to engage in active learning by doing. This model provides students with real world experience to better prepare them for work and careers. The active learning concept and the importance of engaging the student will be examined. (key words-active learning, experiential learning, cooperative learning)
\end{abstract}

\section{INTRODUCTION}

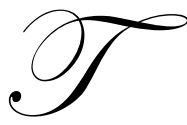

he U. S. Small Business Administration (SBA) administers the Small Business Development Center Program (SBDC) to provide management assistance to current and prospective small business owners. SBDCs offer one-stop assistance to individuals and small businesses by providing a wide variety of information and guidance in central and easily accessible branch locations. Rhodes State College in Lima, Ohio is the regional host (Region \# 3) for the SBDC in West Central Ohio. The program is a cooperative effort of the private sector, the educational community and federal, state, and local governments. It enhances economic development by providing small businesses with management and technical assistance.

In August of 2006, the Nxlevel Entrepreneurial Training Program was started as a pilot in a Business Research Class at the University of Findlay where six teams of students and six local businesses worked in collaboration to develop a business plan. This pilot project blended theory and practice exposing the students to local entrepreneurial businesses. Our experience suggests that bringing the business owners into the classroom and teaming them up with students produced an entrepreneurial, experiential, and supportive education learning environment. Nxlevel is designed to help entrepreneurs learn the skills needed to create, develop and strengthen successful business ventures. Nxlevel addresses the special needs of the entrepreneur by providing a practical, hands-on, common sense approach to developing their small businesses... whether they are just starting out or ready to grow. The Nxlevel material is an excellent source for the college students to learn about entrepreneurship as they work closely with their business owner.

Bringing the business owners into the classroom and teaming them up with students was intended to develop the students' understanding of how a business enterprise is conceived, launched and sustained. Because today's marketplace is getting more complex, navigation requires a more sophisticated set of management skills for the successful small business owner and those training for careers in business. In addition, technology is playing a greater role in small business operations and management. A key learning objective of this project was to share the relevant technology applications from the students, educate the business owners and apply the new knowledge into business applications. The key to this program is the emphasis on technology use by the students as some business 
owners lack the technology skills. Websites, brochures, customer databases were key methods developed from this project that will improve the likelihood of success in the small business.

The initiator of knowledge transfer for the students and the business owners took place in discussions, presentations, networking, and the actual business plan creation. The goal of the SBDC was to provide small businesses with a business plan and resources to help them succeed. The goal of the University of Findlay was to provide the students with real-world experience to better prepare them for work and engage them in the community.

A growing number of people think college graduates want to work for themselves rather than a "regular" company. The next ten years will see the most diverse pool of entrepreneurs ever. The competencies mastered in this Business Research Class will expose students to the risks (both financial and personal) taken by entrepreneurs and encourage the students to become future entrepreneurs. This collaborative approach to learning has stimulated learning in entrepreneurship and reflective practice.

This class was designed to give a helping hand for entrepreneurs to reach the next level of success. It also was intended to provide encouragement and ideas to facilitate entrepreneurship education for the students. Both students and business owners developed new skills and gained new knowledge from this experience. The power of collaboration, the spirit of innovation, and the future of learning in a global economy were critical components in the success of the Business Research Class.

The authors believe that every college graduate must have a working knowledge of business plans and a greater appreciation about the environment and life of the entrepreneur. Instead of case studies, this fresh approach to learning provides the student with the opportunity to fully engage in the actual development of a business plan that can be used and implemented by a real entrepreneur.

\section{LITERATURE REVIEW}

There are many terms that describe the various forms of learning with each term having its subtle differences. This paper will briefly identify and define three learning terminologies and relate those terms to how the Business Research Class used them throughout the course. The terms are active learning, cooperative learning, and entrepreneurial learning.

Active learning is any teaching method that gets students actively involved (Keyser 2000).

Active learning can be anything that involves students in doing things and thinking about what they are doing (Bonwell and Eison 1991). Houston (1995) notes that many techniques can be used to get the students involved such as experiential learning, cooperative learning, problem-solving exercises, writing tasks, speaking activities, class discussion, case-study methods, simulations, role-playing, fieldwork, independent study, homework, etc. The Business Research Class used active learning by requiring students to prepare a business plan, make oral and written presentations, use in-class assignments and case studies, conduct market research, engage in class discussion, work closely with their business owner, discuss topics with guest speakers, etc.

Cooperative learning is one approach to active learning. It should be noted that cooperative learning is always active learning, but not all active learning is cooperative. Cooperative learning is the instructional use of small groups so that students work together to maximize their own and each other's learning (Johnson, D.W., Johnson, R. T., \& Smith, K. A., 1991). In order to work well, cooperative learning needs to be planned. Consideration needs to be given to the appropriate size of the group and to each student's role within the group and how the results will be evaluated and used in the class session. Every student in a cooperative learning group should have a role or part to play in order to accomplish the task. It is not just any "group work." Like active learning, the particular group exercise must be chosen for the academic task and the students who must accomplish it.

Keyser (2000) asserted that using active or cooperative learning techniques does not mean you must leave out lectures entirely. Five to ten minute short lectures can be used to introduce the basic steps of a new skill or new concept according to Keyser. The short lectures can then be followed by an active or cooperative exercise. King 
(1993) suggested that the introduction of each new major concept or principle be followed with some activity that requires the students to generate some meaning or understanding about that concept or skill. King also emphasizes that most learning will take place during the exercises, but the active/cooperative learning techniques cannot be a substitute for the explanatory lecture entirely. Throughout the Business Research Course short lectures were used to introduce the various topics to the students. Following the lectures, exercises and short problem cases were used to provide the student groups the opportunity to apply the new knowledge and concepts. Lively group discussions and dialogue would take place after each group completed the exercise questions. Further learning would take place following the discussions with a period of reflection of the key topic points.

Keyser also cites several writers that provided rationales for the use of active or cooperative learning techniques in library instruction. "One of the primary tenets of cooperative learning is that, if instructors are prepared to give up some control, students will learn more and retain that knowledge longer" Mabry (1995). Allen (1995) cites the writings of several researchers to show that active learning leads to increases in student learning and interest. Other benefits of this style of teaching would include meeting the needs and learning styles of diverse students, as well as, improving student retention. Increasing student interaction with information and increasing student responsibility for their own learning throughout the course are also benefits of this teaching style (Ridgeway 1989; Sheridan 1990; and Jacobson and Mark 1995). Some of the exercises used in the Business Research Class would require the students to leave the classroom and do research in the computer lab. A time limit would be given along with general guidelines for deliverables by the group. Giving the student groups' latitude in their deliverables encouraged creativity, increased their interest, and gave a sense of adventure as the groups' would assemble the results of their findings. Generally, each group would be required to present their findings to the other groups. After each presentation, discussion was encouraged.

According to Keyser's study on library instruction, choosing a technique to use begins with identifying what it is you want the students to learn. Identifying the goals and objectives are important as it provides focus and direction for both the instructor and student. Furthermore, Allen (1995) states that planning and organization is essential to good teaching. Instructors must know what they want to teach or what they want the students to learn. The goals and objectives were clearly stated by the Business Research Course instructors as found in the course syllabus, schedule of assignments, and the use of rubrics. Many hours were devoted to designing this course and planning its curriculum. Identifying the key topic areas that we wanted the students to learn provided a clearer understanding of the course expectations for the students.

Entrepreneurial learning. Pittaway and Cope (2007) reference the following quote: "Effective entrepreneurs are exceptional learners. They learn from everything. They learn from customers, suppliers, and especially competitors. They learn from employees and associates. They learn from other entrepreneurs. They learn from experience. They learn by doing. They learn from what works and, more importantly, from what doesn't work." (Smilor, 1997).

The Business Research Course provided the venue for entrepreneurial learning for the students and the business owners and the instructors, too! The students would learn from the experiences of the business owners and the instructors. The business owners would share with the students what did and didn't work for them. The business owners would learn from the students' experiences and knowledge attained from their college courses, as well as, from the students' competencies in technology. The students learned how to develop a business plan by actually creating one for their business owner. The business owner learned about the business plan through the students' presentations and many discussions between them. The instructors continued to learn from working with the various types of businesses and the different opportunities that the business owners brought to each course.

Pittaway and Cope examined the key processes about entrepreneurial learning and how those processes might be simulated in a student-learning environment. They developed a new venture planning (NVP) course to explore how such courses can promote entrepreneurial learning by simulating learning by engaging the student in experiential learning and reflective practice. The NVP courses ask students to develop business ideas and work on detailed business plans to turn their ideas into commercially viable propositions. Seventy-three students completed the course, working in 15 teams were examined in the NVP courses. The strength of the NVP course is that it provides students the opportunity to apply and adapt their knowledge from a wide range of management disciplines. 
Pittaway and Cope note that it provides "a practical and integrative pedagogic approach to entrepreneurship education." The NVP course requires the creation of a business plan which requires the students to "visualize the complex interdependency between different management subjects such as finance and marketing." Using the students' prior experience of other management education courses, the students have the opportunity to apply that knowledge into the project, thus adding value to the project and to the course from which the knowledge was taken. The activities within the Business Research Course such as creating a business plan and using the students' prior experience from other business-related courses to add value to the business plan are clearly supported by Pittaway and Cope as a form of entrepreneurial learning.

Taylor and Thorpe (2004) note that actual experiences can shape learning. Actual experiences would include having actual entrepreneurs come into a classroom to share their experiences as we did in the Business Research Course. Taylor and Thorpe describe it as a "process of co-participation" where learning involves "reflecting, theorizing, experiencing and action" (p204). Throughout the course semester, the students actively participated with other team members, other groups, and with their business owners. Each class session would include a period of reflection along with opportunities to theorize about the various issues that were raised during that class session.

Entrepreneurs learn by overcoming opportunities and problems (Reuber and Fischer, 1999; Young and Sexton, 1997; Minniti and Bygrave, 2001). Recent research argues for a view that entrepreneurial learning should be seen as a social phenomenon (Rae, 2002; Hamilton, 2004) and entrepreneurs be viewed as practitioners who operate in social communities of practice (Hamilton, 2004; Cope, 2005). In this project, the students acted as "business advisors" or practitioners by helping the business owners develop solutions to business questions and problems.

Fiet (2000) discusses the issues concerning the difficulty with teaching theory to entrepreneurial students in that many complain that "Theory is boring! Lectures are boring! School is boring!" Fiet cautions that instructors become boring when the classroom style becomes predictable and unable to apply theory in surprising ways. The goal for course learning was to ensure that students will master specific competencies. Fiet suggests that the teacher's approach not be "What am I going to teach today", but "What am I going to have my students do today?" This approach can be delegated to the students along with some boundaries set by the instructor which the student activities may be selected. Fiet states that delegating the responsibility for the selection of specific learning activities to the students can introduce more variety and surprises into the classroom. This approach can alleviate boredom. Student-led activities place the responsibility of learning, the sharing of ideas and concepts to the students. In the end, the students are responsible for their learning. The authors of this article used the approach "What am I going to have my students do today?" to engage the students in specific learning activities. Using small groups, the students would lead various discussions, share ideas and concepts to the other students. Many of the activities were based on various issues pertaining to their business owners. The students analyzed real problems and issues as opposed to working with just "theory".

Solomon (2007) studied the current state of entrepreneurship education in the USA for the years 2004-5. A national survey resulted in 270 schools responding. The survey found that the use of technology examined in prior national studies have continued in a similar direction and in some areas, the use of technology has increased dramatically. The survey's findings confirm that the traditional teaching method of requiring students to create a business plan is still used. The survey data showed that entrepreneurship educators are increasing using guest speakers and class discussions more frequently than the traditional approach of class lectures. The Business Research Course used the creation of business plans by the students and invited guest speakers into the classroom as methods for teaching entrepreneurship education. These methods are clearly supported by Solomon's study as viable teaching methods for entrepreneurial learning.

Offering students opportunities to "experience" entrepreneurship and small business management has been the theme for many entrepreneurial education programs. McMullan and Long (1987) stated that effective entrepreneurial education requires students to have substantive "hands-on" experience in working with community ventures so they can learn to add value to real ventures. 
Garavan and O'Cinneide (1994) suggest that the best methods suited to an entrepreneurial learning style are active-applied and active-experimentation. They stress that educational programs and systems should be geared toward creativity, multidisciplinary and process-oriented approaches and theory-based practical applications. Plaschka and Welsch (1990) state that what are needed are a more proactive, problem-solving and flexible approach rather than the rigid, passive-reactive concept and theory-emphasized functional approach. The Business Research Course provided an opportunity for the students to "experience" entrepreneurship by actually working with and developing a relationship with an entrepreneur. The students were proactive in developing solutions to problems for their business owners.

\section{PARTNERSHIP MODEL AND ITS PROCESS:}

Below in Figure 1 is the Partnership Model that consists of the small business owners used in the Business Research Course, the Small Business Development Center (SBDC), The University of Findlay, and the college students enrolled in the Business Research Course.

Figure 1-The Partnership Model

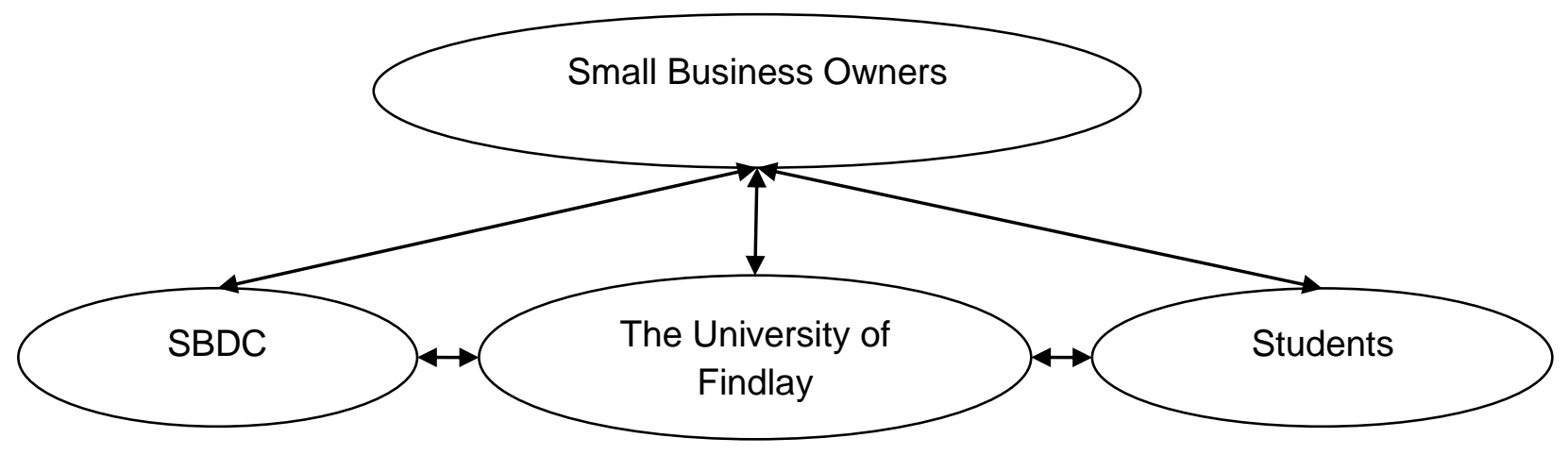

The SBDC director identifies business owners that would be a good fit for the Business Research Course. Businesses are chosen based on types of assistance needed by the owners, the willingness of owner to participate in the partnership, the commitment level of the owner, etc.

The University of Findlay (UF) faculty instructor assigned students to specific groups for each business owner. The groups are determined by student skill sets. The students acted as business advisors in providing suggestions and recommendations to their assigned business owners throughout the project.

The business owners are invited to class to explain their situation and needs. The business owners then meet with their student groups and begin sharing information.

Guest speakers from the community were invited to two class sessions to provide information to student groups and their business owners. The speakers have been CPAs, insurance agents, website designers, and bankers.

Three presentations were made to the business owners throughout the course. The final presentation included a completed business plan and action plan for the owner.

\section{EVOLUTION OF PARTNERSHIP MODEL}

Below is a timeline that captures the beginning of the partnership model to date. 


\begin{tabular}{|c|c|c|c|c|c|c|c|}
\hline July 2006 & $\begin{array}{l}\text { Fall } \\
2006\end{array}$ & $\begin{array}{l}\text { Dec } \\
2006\end{array}$ & $\begin{array}{l}\text { Spring } \\
2007\end{array}$ & $\begin{array}{l}\text { March } \\
2007\end{array}$ & $\begin{array}{l}\text { Fall } \\
2007\end{array}$ & $\begin{array}{l}\text { Spring } \\
2008\end{array}$ & $\begin{array}{l}\text { Fall } \\
2008\end{array}$ \\
\hline $\begin{array}{l}\text { SBDC Director } \\
\text { and } C O B \text { meet }\end{array}$ & $\begin{array}{l}\text { Purchased } \\
\text { NxLevel } \\
\text { material for } \\
\text { course \& } \\
\text { started pilot } \\
\text { in Business } \\
\text { Research } \\
\text { class (6 } 6 \\
\text { teams of } \\
\text { students } \\
\text { and } 6 \\
\text { businesses } \\
\text { involved) }\end{array}$ & $\begin{array}{l}\text { Completed } \\
\text { pilotwith } 6 \\
\text { business } \\
\text { owners }\end{array}$ & $\begin{array}{l}\text { Ran second } \\
\text { section with } \\
6 \text { business } \\
\text { owners }\end{array}$ & $\begin{array}{l}\text { Team from } \\
\text { Fall } 2006 \\
\text { present at } \\
\text { the Small } \\
\text { Biz Expo at } \\
\text { the State } \\
\text { Capitol in } \\
\text { Columbus }\end{array}$ & $\begin{array}{l}\text { Ran } 3^{\text {rd }} \\
\text { section } 4 \\
\text { business } \\
\text { owners }\end{array}$ & $\begin{array}{l}\text { Ran 4th } \\
\text { section } 4 \\
\text { business } \\
\text { owners } \\
2 \text { students } \\
\text { present at } \\
\text { Small Biz } \\
\text { Expo at the } \\
\text { State Capitol } \\
\text { in Columbus }\end{array}$ & $\begin{array}{l}\text { Run } 5 \text { th } \\
\text { section } ~ \\
7 \text { business } \\
\text { owners!! }\end{array}$ \\
\hline
\end{tabular}

In July 2006, the SBDC director began searching for assistance to help with the increasing number of entrepreneurs needing counseling. The director visited The University of Findlay and met the marketing director. After several meetings, they agreed that teaming students with business owners with the goal of writing business plans would provide experiential learning opportunities for the students and provide assistance for the business owners. This pilot would be placed in the Business Research Course and was approved by the dean of the business college. The NxLevel material was used as the referenced text. The first class began in the fall 2006 with six teams of students. The types of businesses used in the first session were curbside recycling, massage center, rum cake, new product (planter), and metal art with new product added, and a non-profit.

The second class ran in the spring 2007 with six teams of students. A team from fall 2006 course shared their experiences of the pilot course at Small Biz Expo at the State Capitol in Columbus, OH. The types of businesses used for the second semester were office supply/PC, biodiesel lid (new product), pet grooming, tattoo business, t-shirt screening/sports equipment/clothing, and a dipping sauce (new product).

The fall 2007 course had four teams of students with the following types of businesses: automotive oil changing, tooling, fragrance products, and window cleaning.

The spring 2008 was the fourth class with five teams of students. The types of businesses used for this semester were financial services, roller skating rink, radio station, handyman service, and photography. A faculty member and two students from former teams again presented their experiences to the Small Biz Expo at the State Capitol in Columbus, Ohio. The SBDC advisor, authors and two students provided marketing ideas for a small business owner (outside of semester). In June 2008, the partnership model was presented to SBDC Region \#2 in Toledo, Ohio. They plan to "benchmark" the model by partnering with a local university.

There will be approximately seven business owners that will be assisted for the fall 2008 semester.

\section{COURSE DELIVERABLES REQUIRED BY STUDENT GROUPS}

The student teams were required to make three fifteen minute presentations during the course semester. Each presentation assignment had specific requirements and deliverables (see below): 
- $\quad$ Presentation \#1: SWOT analysis, marketing analysis, competitive analysis, PEST analysis (political, economic, social, technical)

The first presentation consisted of four comprehensive analyses. It was based on the information gathered from conversations from interviews, phone calls, and emails with the business owner. The students conducted research using the internet and actual field investigations.

A question and answer session was held after each presentation. An updated business plan was required by each group. This paper documented the detail noted within the presentation.

The SWOT analysis helps the student gain better understanding about their business owner by identifying the strengths and weaknesses of the business (internal examination). The students also examined external factors through assessing the opportunities and possible threats which may impact the owner.

The marketing consisted of a detailed analysis of the business's targeted customers (A, B, C) with both demographics and psychographic information. The owner's use of media and advertising costs were examined. All four P's of marketing (price, product, promotion, and place) were reviewed.

The competitive analysis was conducted by comparing the business to at least three major competitors. A form was used by the group which used criteria such as products, price, quantity, customer service, reliability, expertise, image/reputation, location, etc. as a basis for the comparative study. The group ranked each competitor and its own business owner for each factor.

The PEST analysis was conducted which reviews how potential political, economic, social, and technology issues might impact the business owner.

- $\quad$ Presentation \#2: Marketing (advertising) and Financial Analysis

A question and answer session was held after each presentation. An updated business plan detailing all of the research and costs was required by each group. This paper documented the detail noted within the presentation.

The following requirements were for the second presentation:

Ads for target customer-Each group was required to design three different types of media ads. The ads were to focus on their owner's various target customers ( i.e., customer group A, customer group B, customer group C).

Proforma income statement-- Each group was required to develop a proforma income statement which captured the income and costs of operating their owner's business.

Plan for growing the business - Each group was required to provide detail on how they would plan to grow their owner's business. The plan should include specific details of their strategy along with identifying who would be accountable for carrying out the details of the plan.

Community involvement-Each group was required to develop a list of opportunities for their owner to get involved and learn the value of networking with other business owners.

Start doing and stop doing - Each group was required to provide a list of actions that the owner should begin to "start doing" and "stop doing". One example of a business should "start doing" was to keep track of travel expenses for both tax and price purposes. An example for a business that should "stop doing" was to stop giving discounts to every customer that asks for one.

- $\quad$ Presentation \#3: The Completed Business Plan with an Action Plan

A question and answer session was held after each presentation. The focus of the presentation was to highlight the key components of the business plan and provide guidance on how to implement their action plan. After all of the groups made their presentations, each group met with their business owners to discuss in greater detail their business plan/action plan and provided a written copy and CD of the business plan to their owner and to the instructor.

\section{SUCCESS STORIES}

Below are several success stories that resulted from implementing the business plans by several of the business owners and going through this college course.

- $\quad$ The business owner who created a beef and bean dip began selling the product to local grocery stores. In the fall 2008, it will be distributing product in seven states. The business originally began in his home and then moved to a kitchen incubator. The business owner is producing and packaging the product in Ohio. 
- The flower pot business secured the needed financing and is manufacturing the product in Ohio and distributing throughout the US. The business has expanded into India and is planning on expanding operations in Europe.

- $\quad$ The roller skating rink business used the business plan created by the students to secure loan to finance a building addition and to purchase equipment for selling ice cream. The idea to sell ice cream was suggested by the students in presentation \#2-how to grow the business.

- $\quad$ The business owner with the new trailer hitch prototype is currently being reviewed by ten manufacturers and a video has been developed to promote it. Patents are pending and the potential revenue stream is over $\$ 1$ million over the next 15 years.

\section{PROJECT FEEDBACK}

At the time of this writing, twenty-one business owners have been assigned to college student teams. Feedback was collected from the business owners, students, and the SBDC director.

Overall, the feedback from the business owners was very positive. Some owners found that advertising in the local newspaper may be way to best reach their target market. Many owners noted that actually going through a business plan and answering the questions made them view their business in a different light. Several owners commented favorably about the students' positive attitudes and their technical knowledge. One owner mentioned that being more "tech savvy" could save him time and make work easier. Witnessing the benefits of using the internet by the students during the Business Research Course, some owners mentioned they would begin selling their products on the internet.

As one of the least successful parts of the project, one owner commented that he wished he would've had more time with the students outside the class and could've come to all the classes. Another owner mentioned the disappointment of not getting the materials from the student team. The student team was not able to complete a brochure for the owner due to time constraints and resources.

Feedback from the students over the past two years has been outstanding. The students noted the value of sharing information and being creative to accomplish goals. They mentioned that the project gave them a small taste of the business world. Getting to do a business plan and giving presentations was also extremely beneficial. They learned how to work with actual business owners instead of case studies. This activity gave them the opportunity to apply their knowledge and gain experience before entering the workforce.

Several student teams mentioned that their owner was not very accepting of change and was difficult to get in contact with. Other groups mentioned the difficulty in getting financial data.

One student commented that the project demanded a lot of time and hard work outside of class. The student had to take time off work to complete the project requirements. Several student teams mentioned that working in groups was sometimes difficult, but nothing that couldn't be resolved.

The students were asked to comment about any new skills or new knowledge they attained from the project. Many students mentioned their communication skills improved by communicating with different types of people within their group. Others mentioned their teamwork skills improved during the project and would be very beneficial in their future. Several students mentioned the value of learning how to plan to cover operating costs and liabilities. Some students commented that learning how and who to network with was a benefit from the course.

Lastly, the students were asked to make any additional comments about the course. They noted that creating an actual business plan is very rewarding and this is one of the best classes they have taken. The course was very time consuming. It was also mentioned that it was a lot of work but assisting a small business was the reward and being able to apply the knowledge that we learned during our college careers was exciting. 


\section{FACULTY OBSERVATIONS ABOUT THE PROJECT}

There were many observations made by the course professors that should be noted about the project. The key ones are listed below:

- $\quad$ Experiences from this course can provide excellent discussions in other courses such as entrepreneurship, entrepreneurial finance, marketing/advertising, etc. The students in the other courses enjoy discussing actual business issues.

- $\quad$ Dealing with a new group of business owners each semester meant many hours of learning about each new business by the instructor. Keyser (2000) suggested that instructors should allow a reasonable amount of time to plan for classes that apply active or cooperative learning and warns that changing your teaching style will feel awkward at first.

- Having heard about the partnership model, a local community association leader approached one of the project professors to request ideas for bringing more customers to shop downtown during the Christmas season. This was an excellent opportunity for case analyses for other business courses.

- The project creates a win-win situation for the students, owners, university, and community. The students learn by doing by becoming "business advisors" and developing business plans. The owners win by receiving a business plan and marketing ideas from the students. There is no charge to the business owners. The university wins by getting publicity about the project by the local business owners and the SBDC.

- $\quad$ The students' confidence grew as they worked with the business owners. Realizing that the owners needed help, the students became fully engaged by developing ideas to aid in resolving problems.

- $\quad$ Using her experience from this project and her experience in presenting at the State Capital, a former student was able to secure a spot in a management training program in her job. This experience can help other students secure future positions in their careers. This opportunity to work in teams and act as business advisors can be detailed on the students' resumes. Having this experience could be one of the factors that differentiate them from their peers in getting a job.

\section{FACULTY OBSERVATIONS ABOUT THE BUSINESS OWNERS}

The key faculty observations about the owners are noted below:

- $\quad$ Focus--Some owners had difficulty in focusing on core business issues. This led to needed discussions about defining the problem.

- $\quad$ Documentation methods--Many owners did not have a customer database. One student team created a file for the owner to capture data about their customers.

- $\quad$ Understanding costs--Several of the owners did not know the costs of making the product nor keep detailed records of the amount or number of discounts being offered to their customers. This provided an excellent learning opportunity for the students and the business owner on the importance of knowing yours costs in order to develop appropriate pricing and profit forecasting.

- $\quad$ Pricing--There was a general tendency by the business owners to under-price their products and services. The owners and teams soon realized how their financial position could change by value pricing their products and services competitively.

- Technology challenges-Most of the business owners did not have websites or computer systems. It was found that those owners with websites were generally out of date and had not been maintained. This provided an opportunity for the student teams to use their computer/internet skills to developing solutions for their owners.

- $\quad$ Reluctance by owner to accept students' suggestions-Most owners were open to the students' suggestions and were very grateful for the hard work and energy that the students gave to the project. However, several owners did not agree with the suggestions. The students were disappointed that the likelihood of the owner to act on their recommendations contained in the action plan would be remote. This was an opportunity for the professor to provide encouragement to the teams. The professors commented that if the owner is rejecting the advice now, it doesn't mean that later on that some of the recommendations might be 
used. The students' job is to provide ideas for the business owners. It is the owner's decision if and when to implement the recommendations.

\section{FACULTY OBSERVATIONS ABOUT THE STUDENTS}

The key faculty observations about the students are noted below:

- Communication with owners nonexistent or slow-It was noted in several student teams that the communication with the owners was slow to develop. This could be the result of students being hesitant of breaking out of their comfort zone in working with their owners. Perhaps working with real people in real business situations was intimidating for some students. Most of the teams, however, developed a relationship with their business owner immediately. This was very encouraging to see the students asking many questions and gathering as much information as possible from the owner during the very first meeting with the owner.

- $\quad$ Team dynamics - Each student team was responsible for facilitating the business plan, delegating various responsibilities and deliverables to each other, and identifying timelines for the deliverables. Most groups worked very well together. There were only several groups that expressed frustration of a group member not performing and meeting the team's requirements.

- $\quad$ Lack of research experience/skills - Some students lacked the research skills necessary in gathering information that was needed to complete the business plan.

- $\quad$ Easily frustrated and impatient-Some students found this project overwhelming in the beginning. Doing something new such as working in teams with students and a business owner, being responsible for a business plan and an action plan can cause some students to become frustrated and impatient. At this point, the instructor would discuss with the teams the importance of working together as a team and it is not unusual to become frustrated or impatient at the start of doing something new. The teams were encouraged to communicate with each team member and begin developing a stronger relationship.

- Disappointed when owners were reluctant to accept new ideas or suggestions-On several occasions, the owners were not willing to implement the ideas found in the action plan. The students showed signs of disappointment, but were encouraged by the professor to provide the best action plan possible. The professor emphasized that it was the owner's decision whether or not to implement the action plan.

\section{OVERALL PROJECT BENEFITS}

The project provided a benefit to all parties within the partnership model. Below is a brief summary of those benefits:

- $\quad$ Students- Students were exposed to the real life activities of entrepreneurs. Students acted as business advisors to the business owners and learned how to analyze and evaluated the environment that the business owner faces. Students have been able to use their experiences from this course as talking points during job interviews.

- $\quad$ Business Owners-The business owners enjoyed the benefit of both university faculty and students' knowledge and expertise. They also received "free" consultation services, a completed business plan and an action plan for their future. Several of the business owners utilized regional packages and distribution sources to manufacture their products. They felt it was important to support other small entrepreneurs.

- $\quad$ Faculty facilitators-The professors continued to develop their consulting skills by working with business owners and assisting the students in developing business plans.

- $\quad$ SBDC-The SBDC was able to accommodate more business owners by using this partnership model. Also, other regions in the state can emulate this partnership model.

- The University - The university benefits in recruiting students by advertising that it uses "experiential learning" to educate its students. "Hands on" learning is a more preferred method of learning by students than lecture based learning (Keyser 2000; Allen 1995; Mabry 1995; Pittaway and Cope 2007). 
Based upon the comments from the students, the authors found value in the use of short lectures that were used to introduce the basic steps of a new skill or new concept. The short lectures were then followed with an active or cooperative exercise as supported by King (1993). Most of the exercises were performed by the teams. This generated discussion within the teams and strengthened their communicative and interactive skills. The next step of the exercise would be a discussion that included the entire class. This provided the opportunity for the teams to share their ideas and thoughts with their classmates.

Although the course project was well-planned, organized, and student outcomes defined, the professors were willing to give up control and allow the students to develop the business and action plans on their own. The result of this approach is that students will learn more and retain that knowledge longer (Mabry 1995). As noted earlier, this form of active learning leads to increases in student learning, retention, and interest as well as meets the needs and learning styles of diverse students (Allen 1995).

The authors strongly agree with Keyser (2000) that instructors should identify what it is you want the students to learn. Detailed rubrics were provided to the students which specifically identified the requirements and points assessed for each presentation and elements of the business plan. The authors also suggested that planning and organization was essential to good teaching as supported by Allen (1995). The authors identified the goals and objectives for the project. At the conclusion of each course semester, the instructors discussed the strengths and weaknesses of the course format. In doing so, changes were made to improve the course for the next semester.

The project encouraged the students to become practitioners by taking on a new persona by acting as a "business advisor". The project provided learning opportunities by working in teams and working with real problems with real business owners. The course format was designed as a "learn as you go process". Students completed a business plan in phases and conducted market research by actually doing it. This approach was sometimes new to students which forced them to break out of their comfort zone and apply themselves. The professors became learning coaches by encouraging the students to go beyond their comfort zones. The project challenged the students by requiring them to take responsibility and ownership for their own learning and group dynamics.

Another learning benefit of the project was that each team had to work within tight timeframes and to perform under some pressure. This led to the students' development of time management skills, delegation of tasks, communication skills, the realization of the commitment involved when starting and operating a business. The students observed the need to make do with less than perfect information and that owning a business involves trial and error, experimentation, and problem solving.

In essence, this project encompassed action learning, cooperative learning, experiential and entrepreneurial learning. It provided students with the opportunity to learn by doing. Based on the student feedback, they appreciated this new and fresh approach to learning.

\section{INSTRUCTORS' ADVICE ABOUT THE NEW APPROACH-WHAT WORKED AND WHAT DIDN'T WORK}

During the first two semesters, the team size was generally five to six students per team. It was observed by the professors that some students were not as engaged as other team members. Beginning in the second year of the project, student team sizes were decreased to three to four students per team. It was observed by the professors that smaller team sizes appeared to engage and involve the entire team.

The communication between the student teams and their owners was generally good. However, there were several occasions where the students complained that the owners were not responding to emails or phone calls. This led to the implementation of a communication log that would be maintained by the student teams. The dates, times, and method of communication would be entered on the communication log. At the beginning of each new semester, it was agreed that the owners and the student teams would respond within 48 hours to any form of communication by the other party. 
After being selected by the SBDC to participate in this project, several business owners did not fully participate. Several owners did not respond to student inquires or attend the student team presentations. This led to the development of a letter of commitment between the business owner and the SBDC at the beginning of the second year of the project. The letter of commitment stated that the business owner would participate in the activities of the project and would communicate with the student teams. The letter of commitment would be signed by the business owner and the SBDC director prior to the start of the course semester. The implementation of the letter of commitment has resulted in very few complaints from the students about the participation level of their owners.

The project used the NxLevel materials for the course text. It is used as a source of reference by the students in learning about developing business plans. The professors used it as a source for lecturing and providing exercises to the students. The students have responded very favorably to keep the text noting it is "student friendly".

The professors will continue to assign students to the various student-business owner teams. The goal was to provide each team with a blend of student skills in the areas of marketing, finance, management, etc. The project professors have taught most of the students prior to taking this course. The professors have a good feel about the students' skill levels and leadership abilities as they form the teams. At this point, no students have complained about their team assignment. The overall quality of the business plans and action plans have been very good.

The first year of the project did not require an action plan. Upon receiving their completed business plan at the end of the semester, many business owners did not know what their next step should be. In the second year of the project, a detailed action plan was added as a requirement to the business plan. The action plan identified the specific steps or actions that the owner should take. Each step would be assigned a completion date such as in the next 30,60 or 90 day period.

Will the owners go the last 10 yards to make changes in their businesses? Currently, there is no follow-up procedure between the business owner and the SBDC in implementing the action plans. The professors and the SBDC director are currently working with each other to discuss a proposal for business owners to submit a progress report to the SBDC within six months of receiving their business and action plans.

\section{CONCLUSION}

The authors and the local SBDC director believe this model should be implemented by other SBDC regions. This partnership model was introduced to the Toledo SBDC region. A local university is planning on adopting this model during the next school year.

The SBDC director and the authors are concerned that some of the business owners do not implement the recommendations set forth in the action plan. At this time, there is no follow-up procedure by the SBDC director, student teams, or the professors with the business owners. The SBDC director is looking at the possibility of setting up a six-month follow-up procedure with the business owners to determine the extent to which any progress is being made by the business owner.

The authors are attempting to expand the model to include a student intern for the business owner. A grant is currently being written to provide the business owners with a student intern to help implement the action plan that was recommended by the student team.

The partnership model can be expanded to pair students, faculty and new business owners outside the course semesters. There are small businesses that need assistance or help with smaller problems. At this point, time and energy become major issues. Professors, students, and business owners have only so much time and energy to devote to projects. The authors and several students have engaged in working with some business owners in the area of marketing issues. Usually only 2 to 3 hours are devoted in providing guidance and recommendations to the business owners. 
Bringing business owners into the classroom so that college students have the opportunity to work with today's business issues is very rewarding for the student, the business owner, the professors, and the university. Students are better prepared in dealing with business issues as a result of their "hands-on" experience. Overall, the students became fully engaged in this "learning-by-doing" approach, recommended the course to other students and often formed a long-term relationship with the owner. After their last class meeting, the students' expressed their satisfaction and gratitude with this approach.

\section{AUTHOR INFORMATION}

Dan Yates is an assistant professor of business at The University of Findlay. His teaching interests are entrepreneurship, leadership, and business strategy. Yates holds a PhD degree in Management from Northcentral University. He also has a MBA from University of Dayton, a Master of Organization Development degree from Bowling Green State University, and a BS in Accounting from Tiffin University. He has 30 years industrial and governmental experience. He operates Yates Consulting which provides consulting services for individuals and small business owners.

Dr. Ward has been an active faculty member, adjunct since 1998 and full-time with The University of Findlay since 2004. Professor Ward brings her expertise from two Fortune 500 companies into the classroom teaching operations and logistics, marketing, management, strategy and policy, communications, and research. She is the co-advisor for the Rotaract Club, advisor to the Marketing Club, and serves as the Lead Professor in Marketing for the College of Business. Her service to the community includes positions on the Small Business Advisory Council, Owens Community College Business Advisory Board, local school strategic planning committee, and multiple non-profit committees.

Professor Ward holds the following degrees: University of Sarasota, Ed D, Organizational Leadership; The University of Findlay, MBA; The University of Findlay, Bachelor of Science in Business Administration; Owens Community College, Associate Degree in Business Management. She is also a Six Sigma Black Belt and 2008 Ohio Partnership for Excellence Examiner.

\section{REFERENCES}

1. Allen, E. E. (1995). Active Learning and Teaching: Improving Postsecondary Library Instruction. Reference Librarian , 51-52, 89-103.

2. Bonwell, C. C., \& Eison, J. A. (1991). Active Learning: Creating Excitement in the Classroom. Washington, D.C.: The George Washington University (ERIC Clearinghouse on Higher Education.

3. Cope, J. (2005). Toward a Dynamic Learning Perspective of Entrepreneurship. Entrepreneurship: Theory and Practice , July, 373-98.

4. Fiet, J. O. (2001). The Pedagogical Side of Entrepreneurship Theory. Journal of Business Venturing, Vol. $16,101-117$.

5. Garavan, T. N. (1994). Entrepreneurship Education and Training Programmes: A Review and Evaluation. Journal of European Industrial Training, Vol. 18, No. 8, 3-12.

6. Hamilton, E. (2004). Socially Situated Entrepreneurial Learning in Family Business. Proceedings of the 27th ISBA National Small Firms Policy and Research Conference. Newcastle, November.

7. Houston, J. (1995). Thesaurua of ERIC Descriptors, 13th edn. (p.8). Phoenix, AZ: Oryx Press.

8. Jacobson, T., \& Mark, B. L. (1995). Teaching in the Information Age: Active Learning Techniques to Empower Students. Reference Librarian , 51-52, 105-120.

9. Johnson, D. W., Johnson, R. T., \& Smith, K. A. (1991). Nuts and Bolts of Cooperative Learning, pp. 1-3. Edina, MN: Interaction Book.

10. Johnson, D., Johnson, R. T., \& Smith, K. A. (1991). Active Learning: Cooperation in the College Classroom. Edina, MN: Interaction Book.

11. Keyser, M. W. (2000). Active Learning and Cooperative Learning: Understanding the Difference and Using Both Styles Effectively. Research Strategies, Vol. 17, Issue:1, Spring , 35-44.

12. King, A. (1993). From Sage on the Stage to Guide on the Side. College Teaching 41 (Winter), 30-35. 
13. Mabry, C. H. (1995). Using Cooperative Learning Principles in BI. Research Strategies, 13 (Summer), 182-185.

14. McMullan, W. E., \& Long, W. A. (1987). Entrepreneurship Education in the Nineties. Journal of Business Venturing, Vol. 2, No. 3, 261-75.

15. Minniti, M., \& Bygrave, W. (2001). A Dynamic Model of Entrepreneurial Learning. Entrepreneurship: Theory and Practice, 25 (3), 5-16.

16. Pittaway, L., \& Cope, J. (2007). Simulating Entrepreneurial Learning: Integrating Experiential and Collaborative Approaches to Learning. Management Learning , 211-233.

17. Plaschka, G. R., \& Welsch, H. P. (1990). Emerging Structures in Entrepreneurial Education is Beginning. Entrepreneurship Theory and Practice, Vol. 14, No. 3, 55-71.

18. Rae, D. (2002). Entrepreneurial Emergence: A Narrative Study of Entrepreneurial Learning in Independently Owned Media Businesses. International Journal of Entrepreneurship and Innovation , 3 (1), 53-59.

19. Reuber, A. R., \& Fischer, E. (1999). Understanding the Consequences of Founders' Experience. Journal of Small Business Management, 37 (2), 30-45.

20. Ridgeway, T. (1989). Integrating Active Learning techniques into the One-hour Bibliographic Instruction Lecture. In J. \&. G. E. Mensching, Coping with Information Illiteracy: Bibliographic Instruction for the Information Age (pp. 33-42). Ann Arbor, MI: Pierian Press.

21. Sheridan, J. (1990). The Reflective Librian: Some Observations on Bibliographic Instruction in the Academic Library. Journal of the Academy of Librarianship, 16 (March) , 22-26.

22. Soloman, G. (2007). An Examination of Entrepreneurship Education in the United States. Journal of Small Business and Enterprise Development, Vol. 14, No. 2, 168-182.

23. Taylor, D. W., \& Thore, R. (2004). Entrepreneurial Learning: A Process of Co-participation. Journal of Small Business and Entreprise Development, 11 (2), 203-11.

24. Young, J. E., \& Sexton, D. L. (1997). Entrepreneurial Learning: A Conceptual Framework. Journal of Enterprising Culture, 5 (3), 223-48. 